\title{
Rainfall characteristics and thresholds for periglacial debris flows in the Parlung Zangbo Basin, southeast Tibetan Plateau
}

\author{
Mingfeng Deng, Ningsheng Chen* and Haitao Ding \\ Key Laboratory of Mountain Hazards and Surface Processes, Institute of Mountain Hazards and Environment, \\ Chinese Academy of Sciences, No. 9, Section 4, Renminnanlu Road, Chengdu 610041, Sichuan, \\ People's Republic of China. \\ *Corresponding author. e-mail: chennsh@imde.ac.cn
}

MS received 20 August 2016; revised 19 December 2016; accepted 24 June 2017; published online 14 February 2018

The Parlung Zangbo Basin in the southeastern Tibet Plateau is affected by the summer monsoon from the Indian Ocean, which produces large rainfall gradients in the basin. Rainfall data during 2012-2015 from five new meteorological stations are used to analyse the rainfall characteristics. The daily rainfall, rainfall duration, mean rainfall intensity, and peak rainfall intensity are consistent, but sometimes contrasting. For example, these values decrease with increasing altitude, and the gradient is large downstream and small upstream, respectively. Moreover, the rainfall intensity peaks between 01:00 and 06:00 and increases during the afternoon. Based on the analysis of 14 debris flow cases in the basin, differences in the rainfall threshold differ depending on the location as sediment varieties. The sediment in the middle portions of the basin is wet and well structured; thus, long-duration, high-intensity rainfall is required to generate debris flows. Ravels in the upstream area are arid and not well structured, and short-duration rainfall is required to trigger debris flows. Between the above two locations, either long-duration, low-intensity rainfall or short-duration, high-intensity rainfall could provoke debris flows. Clearly, differences in rainfall characteristics and rainfall thresholds that are associated with the location must be considered in debris flow monitoring and warnings.

Keywords. Rainfall characteristics; runoff generated; threshold; debris flows; southeast Tibetan Plateau.

\section{Introduction}

Debris flows can be triggered by rainfall (Stoffel et al. 2011; Schneuwly-Bollschweiler and Stoffel 2012), melt water flow from glaciers or ice particle ablation (Arenson and Springman 2005; Decaulne et al. 2005), or outburst floods from glacier lakes. Rainfall is a common trigger of debris flows (Iverson et al. 1997; Sassa and Wang 2005; Stoffel et al. 2011), and both short-duration, high-intensity and long-duration, low-intensity rainfall can generate debris flows (Rahardjo et al. 2007; Rahimi et al. 2010; Schneuwly-Bollschweiler and Stoffel 2012). In deglaciated areas, the significance of rainfall can decline with the addition of glacier ablation water ( $\mathrm{Lu}$ and $\mathrm{Li}$ 1989; Liu et al. 2013).

Rainfall patterns can affect the initiation of debris flows (Rahardjo et al. 2007; Rahimi et al. 2010; Schneuwly-Bollschweiler and Stoffel 2012). 
Numerical simulations by Tsai and Wang (2011) and Luo et al. (2014) showed that the soil slope stability and depth of landslides depend on the rainfall uniformity. Debris flows in the earthquake-stricken Wenchuan area were classified into three categories, namely, rapid-, intermediate-, and slow-triggering response patterns, according to the rainfall intensity, which is related to rainfall patterns (Zhou et al. 2014). The differences in these categories may be attributed to differences in rainfall percolation, which subsequently affect the soil strength and hydraulic conductivity (Rahardjo et al. 2007; Luo et al. 2014; Zhou et al. 2014; Noske et al. 2016; Sheridan et al. 2016).

Indeed, the relationship between rainfall intensity and kinetic energy follows an exponential function (Van et al. 2002; Lu et al. 2008; CalvoAlvarado et al. 2014) and may variably affect soil erosion or shallow landslides (Godt et al. 2006; Lin and Chen 2012). The threshold for mass soil movements depends on the rainfall intensity and duration (Chen et al. 2005; Guzzetti et al. 2008; Giannecchini et al. 2012; Zhou and Tang 2014). Additionally, the rainfall pattern can affect the magnitude of debris flows, with long-duration rainfall likely triggering larger debris flows (Zhuang et al. 2009; Stoffel et al. 2011).

The threshold for most debris flows requires build-up of several factors. The distribution of meteorological stations limits our understanding of the distribution of rainfall events and is the largest obstacle in analysing the triggering of debris flows. However, rainfall data is still required to support water and soil conservation and management and flood control. Several meteorological stations were installed in Parlung Zangbo in 2011 to improve the collection of rainfall data. In this study, rainfall data from 2012 to 2015 were analysed to establish the relationship between rainfall events and debris flows.

\section{Study area}

\subsection{Regional background}

The Parlung Zangbo Basin comprises three parts: the main stream, Yigong Zangbo, and Layue Zangbo (figure 1). The Sichuan-Tibet highway stretches along the main stream, where the newest meteorological stations are set.

The study area is located on the eastern side of the bend of the Yarlung Zangbo River between the eastern Himalayas and the Nyenchen-Tanglha Mountains. The basin has a northwest-southeast orientation, covers an area of $11,551 \mathrm{~km}^{2}$ and stretches from Boxoila Ling in the southeast at $5675 \mathrm{~m}$ a.s.l. to $\sim 266 \mathrm{~km}$ to the northwest at $1540 \mathrm{~m}$ a.s.l.

The Tibetan Plateau is a huge platform with high elevation that prevents warm and wet air currents from the Indian Ocean from moving northward; instead, the air currents pass through the Yarlung Zangbo Canyon, forming a tongue-shaped area that experiences heavy rainfall. The Parlung Zangbo Basin lies on the border of the tongueshaped area and has an annual precipitation of 550-1400 mm (TFITP 1982). The annual rainfall in this watershed declines with increasing altitude and is approximately $900 \mathrm{~mm}$ in the middle stream at the Bomi meteorological station. The abundant rainfall and variable terrain favour the development of temperate glaciers in the Tibetan Plateau. In 2013, temperate glaciers covered an area of $2381.47 \mathrm{~km}^{2}$ (Liu 2013) according to TM images (taken by the No. 4 or 5 thematic mappers on the Landsat satellite with a spatial resolution of $30 \mathrm{~m}$ ).

These temperate glaciers are active structures with abundant glacial till, which may produce debris flow. A total of 67 debris flows were identified in the valley from Ranwu to Peilong over a stretch of $271.4 \mathrm{~km}$ ( $\mathrm{Lu}$ et al. 1999). These debris flows can block highways, destroy houses, kill humans, and hurt pedestrians, threatening social development in the region.

\subsection{Debris flow gullies}

Dozens of debris flows have occurred over the past several years, some of which cannot be determined exactly. In our field work, 14 debris flows were determined in eight gullies, and their background is given as follows.

The Motuo watershed covers an area of $2.77 \mathrm{~km}^{2}$, with an east-west orientation and its lowest elevation at $3050 \mathrm{~m}$ a.s.l. (figure 1). The vegetation in this watershed is rich, and bare land could be found in the channel bed and rills. Snow covers the area between 4100 and $4780 \mathrm{~m}$ a.s.l., and glaciers are present in the channel bed above 3780 $\mathrm{m}$ a.s.l. This channel is narrow, with a slope greater than $20^{\circ}$. Granite is predominant in the upstream area, and diorite is predominant in the downstream area. The glacial debris in the channel bed is wet, and water runoff exits below. The entrainment of glacier debris flows by a mixture of glacier melt 


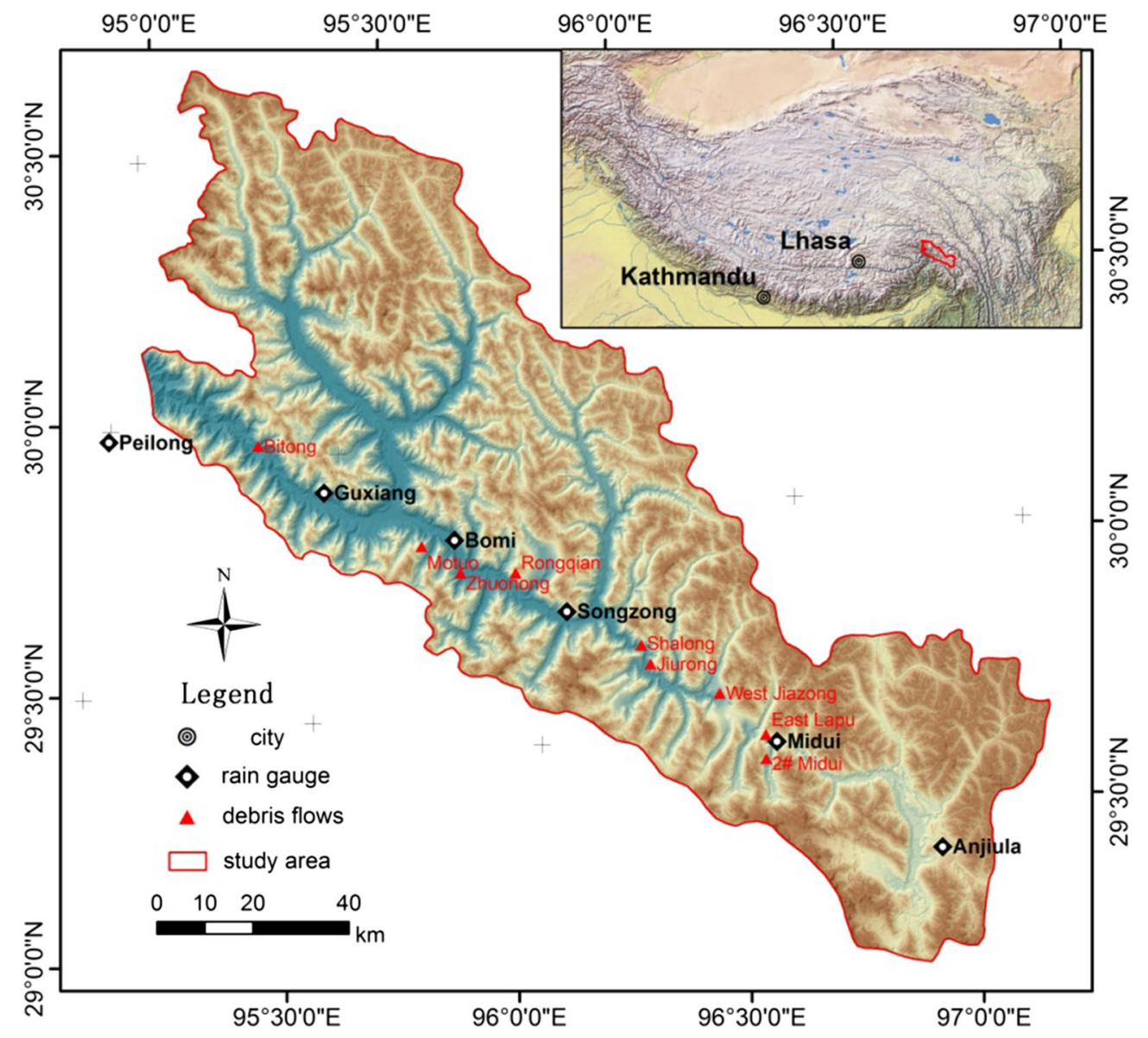

Figure 1. Meteorological stations and debris flows in the Parlung Zangbo Basin.

and rainfall runoff could be responsible for the lone debris flow in 2015.

The Zhuonuo watershed merges with Parlung Zangbo at $2730 \mathrm{~m}$ a.s.l. and covers an area of $4.86 \mathrm{~km}^{2}$ (figure 1). The vegetation in the watershed is thick, and trees occupy most of the land below $3750 \mathrm{~m}$ a.s.l. From 4000 to $4260 \mathrm{~m}$ a.s.l., snow covers the land the entire year, and glaciers exist in small rills. Granite is the sole geology, and the slope is approximately $25-30^{\circ}$. Landslide and rock collapse deposits are quite limited, and ravels from frost weathering can be found in the rills. On the evening of August 19th, debris flows occurred after a long-duration rainfall event. These debris flows had low density and lasted for half an hour.

The Rongqian watershed, which is located above $2850 \mathrm{~m}$ a.s.l., has a drainage area of $4.66 \mathrm{~km}^{2}$ with a north-south orientation (figure 1). Vegetation is rich in the downstream area and sparse with bare bedrock in the upstream area, occupying a large area overall. In the source area, trough glaciers exist between 4173 and $5120 \mathrm{~m}$ a.s.l. in the channel bed, with an area of $4.66 \mathrm{~km}^{2}$ and a surface slope of $30-35^{\circ}$; seasonal snow can be found in the source area. Granite dominates the geology in the upstream area, and diorite is predominant in the middle and upstream areas. Glacial debris is the main soil source, with fewer landslide deposits. Over the past dozen years, debris flows occurred only once on August 19th, 2015; this flow carried large amounts of boulders and large trunks into Parlung Zangbo.

The Shalong Valley merges with Parlung Zangbo at $3150 \mathrm{~m}$ a.s.l. and has a drainage area of 14.96 $\mathrm{km}^{2}$ (figure 1). The channel stretches northeastsouthwest, turning north-south in the middle area and northwest-southeast in the upstream area. Vegetation is sparse, with small shrubs, grassland, and bare land above $4200 \mathrm{~m}$ a.s.l. Glaciers and permanent snow are present in the source area. Slate dominates the geology, and granite can be found in the centre of the downstream area. Dry ravels can be produced by frost weathering and sunlight, which are widely distributed along the slope (gradient of $30-35^{\circ}$ ); additional landslide deposits can 
be observed along the channel. Debris flows in the watershed have been traced since 1990. In recent years, debris flows occurred several times, only one of which (in 2015) we could distinguish.

The Jiurong Valley covers an area of $7.26 \mathrm{~km}^{2}$ and has an east-west fan shape (figure 1). Two symmetrical branches are present; the south branch reaches an elevation of $5230 \mathrm{~m}$ a.s.l. The vegetation in the watershed is sparse, with high trees in the deposition fan, small shrubs in the middle region, and bare land in the source area, which has a slope of $35-40^{\circ}$. Slate is widely distributed, and a band of granite in the downstream area stretches from northwest to southeast. Dry ravels from strong frost weathering are quite rich in the branches and along the slope. Debris flows are very common in the watershed, which can be deduced from the narrowed Parlung Zangbo. We can trace debris flows since the 1990s, and we could distinguish several others from 2014, 2015, and 2016.

The west Jiazong Valley merges with Parlung Zangbo at $3440 \mathrm{~m}$, with a drainage area of $1.72 \mathrm{~km}^{2}$ and a narrow north-south shape (figure 1). Tall trees are present in the downstream area, and bare rock is present in the upstream area. This bare rock has a slope of $22-28^{\circ}$, and the channel gradient reaches $28-35^{\circ}$, where the deposits mainly consist of dry ravels. Granite occupies the entire watershed, although less on steeper slopes. Rainfall runoff that moves through the channel can entrain the debris and trigger debris flows. Debris flows are very common in the watershed, and we collected data from four debris flows over the past several years.

The east Lapu Valley is above $3600 \mathrm{~m}$ a.s.l. and covers an area of $4.25 \mathrm{~km}^{2}$, with an orientation of northeast-southwest (figure 1). High trees are present in the downstream area, whereas the source area is bare. The main channel is long, and several branches are present in the source area with a gradient of approximately $25^{\circ}$. Granite dominates most of the watershed, with a small amount of sandstone and slate in the downstream area near Parlung Zangbo. A large amount of dry debris has accumulated in the small rills, whereas less is present on the slope, which has a gradient of $25-$ $30^{\circ}$. Ancient debris flows cannot be determined, whereas large deposits are present in the fan. Debris flows recently occurred in 2014 and 2015.

The \#2 Midui Valley has a narrow east-west shape and a drainage area of $0.92 \mathrm{~km}^{2}$, with its lowest point above $3730 \mathrm{~m}$ a.s.l. (figure 1). Sparse vegetation is present in this watershed, and small shrubs have only grown in the downstream area. The middle and upper regions are bare and covered by snow and glaciers. The sole stream reaches an elevation of $5350 \mathrm{~m}$ a.s.l., with a large gradient of $22-28^{\circ}$. Sandstone and slate dominate the geology. Dry debris from glacier movement and frost weathering has been deposited in the channel and along the slope. Debris flows are uncommon in the watershed; we could only trace one flow. Additionally, an ancient debris flow deposit is present in the downstream area, although we cannot determine its age.

\section{Data and methods}

\subsection{Data source}

\subsubsection{Rainfall data}

The only meteorological station in the basin is Bomi, which was established in 1955. Bomi is an easily accessible meteorological station with highquality rainfall data. However, the rainfall gradient and isolated rainfall are significant; thus, the Bomi meteorological station's rainfall data cannot reflect the rainfall in the entire basin. Several rain gauges were built in 2011 to better understand the rainfall distribution in the basin and study the triggering of debris flows (table 1, figure 1), and the data from these gauges were used in this study.

\subsubsection{Debris flow cases}

Discipline for debris flow cases. Debris flows are common in the Parlung Zangbo Basin. Debris flows have frequently cut off roads during each year's rainy season. The rainfall threshold for these debris flows is hard to distinguish because of the lack of rainfall data. Debris flows that occurred in the basin after 2011, when more rainfall data could be collected, were recorded to analyse this threshold.

Fourteen debris flows occurred in the summers between 2012 and 2015 and were recorded under the condition that the time of the debris flows could be determined within $24 \mathrm{hr}$ (figure 1, table 2). Because of the sporadic lifestyle of the local residents, debris flows are unlikely to be detected by civilians. Thus, the road maintenance staff records the time when roads are reported to have been blocked by debris flow deposits. Therefore, accurate times of debris flows are quite different than otherwise noted.

Debris flows can be divided into three categories based on the occurrence time. First, the request 
Table 1. Rain gauge information.

\begin{tabular}{llcccc}
\hline No. & Name & Location & $\begin{array}{c}\text { Elevation } \\
(\mathrm{m})\end{array}$ & $\begin{array}{c}\text { Starting } \\
\text { time }\end{array}$ & $\begin{array}{c}\text { Precision } \\
(\mathrm{mm})\end{array}$ \\
\hline 1 & Peilong & $30^{\circ} 02^{\prime} \mathrm{N}, 95^{\circ} 00^{\prime} \mathrm{E}$ & 2030 & 2011.7 & 0.5 \\
2 & Guxiang & $29^{\circ} 54^{\prime} \mathrm{N}, 95^{\circ} 28^{\prime} \mathrm{E}$ & 2664 & 2011.7 & 0.5 \\
3 & Bomi & $29^{\circ} 51^{\prime} \mathrm{N}, 95^{\circ} 46^{\prime} \mathrm{E}$ & 2730 & 2011.7 & 0.5 \\
4 & Songzong & $29^{\circ} 44^{\prime} \mathrm{N}, 96^{\circ} 01^{\prime} \mathrm{E}$ & 3025 & 2011.7 & 0.5 \\
5 & Midui & $29^{\circ} 28^{\prime} \mathrm{N}, 96^{\circ} 30^{\prime} \mathrm{E}$ & 3827 & 2011.7 & 0.5 \\
\hline
\end{tabular}

for clearing debris flow deposits has a time error of $1 \mathrm{hr}$ along the Sichuan-Tibet highway. Second, the Bomi-Motuo highway has relatively fewer cars that pass; thus, reports of debris flows in this area are always delayed, i.e., with a time error of $\pm 12 \mathrm{hr}$. Therefore, the triggering of rainfalls cannot be determined as the time error increases. Third, several debris flows occur near villages; therefore, the local residents can report the time when the debris flows occurred. The time error in this case is approximately $\pm 0.5 \mathrm{hr}$.

\subsection{Methods}

\subsubsection{Rainfall characteristics}

The rainfall duration, peak rainfall intensity, and mean rainfall intensity were applied to analyse the rainfall characteristics. The models included long-term high-intensity rainfall, long-term lowintensity rainfall, short-term high-intensity rainfall, and short-term low-intensity rainfall. The distributions of rainfall duration, peak rainfall intensity, and mean rainfall intensity should be included for larger regional areas. In this paper, the variation in the daily rainfall along Parlung Zangbo is illustrated.

Indeed, the daily rainfall was used first to understand the triggering mechanism and threshold, after which higher-precision rainfall data were used. Debris flows are always triggered by heavy rainfall; thus, heavy rainfall data from June to September were considered. The critical values for heavy rainfall can differ because of the large rainfall gradient in the basin. We define heavy daily rainfall as greater than $25 \mathrm{~mm} / \mathrm{d}$ in Peilong; $15 \mathrm{~mm} / \mathrm{d}$ in Guxiang, Bomi, and Songzong; and $10 \mathrm{~mm} / \mathrm{d}$ in Midui. In addition, the initial hourly rainfall was greater than $0.5 \mathrm{~mm} / \mathrm{hr}$, decreasing below $0.5 \mathrm{~mm} / \mathrm{hr}$ by the end. We ignored rainfall data with problematic GPRS signals in the statistical analysis. Finally, 134 cases over the past 4 years were gathered, including 32 from Peilong, 28 from
Guxiang, 25 from Bomi, 26 from Songzong, and 23 from Midui. Later, these data were applied to analyse the peak rainfall intensity, mean rainfall intensity, and duration during heavy rainfall.

\subsubsection{Rainfall thresholds}

The relationships between the rainfall intensity and duration (Guzzetti et al. 2008; Giannecchini et al. 2012; Zhou and Tang 2014) and the rainfall amount over a certain amount of time are usually applied to determine the rainfall threshold (Chen et al. 2009). The former is widely used with respect to variations in the rainfall intensity with duration, such as I-D curves and C-D curves (Guzzetti et al. 2008), although determining the limit between triggering rainfall and antecedent rainfall is difficult.

In theory, the antecedent rainfall starts at slightly higher than $0 \mathrm{~mm}$ and ends with the triggering rainfall. Generally, the accumulated antecedent rainfall is used (Glade et al. 2000). The triggering rainfall ends with the debris flow, but determining this phenomenon's beginning is not easy. The triggering rainfall value varies with location. In Taiwan, Jan and Lee (2004) adopted a rainfall intensity of $>4 \mathrm{~mm} / \mathrm{hr}$ as the start of the triggering rainfall. In the Wenchuan earthquake area, a rainfall intensity of $>1.0 \mathrm{~mm} / \mathrm{hr}$ was assigned to the beginning (Zhou and Tang 2014). In the study area, the rainfall intensity was smaller than that in Taiwan and was approximately equal to that in the Wenchuan earthquake area; thus, a $1-\mathrm{mm} / \mathrm{hr}$ rainfall intensity was taken as the limit of antecedent and triggering rainfall.

The effect of the antecedent rainfall declines with time, and the exhaustion model by Glade et al. (2000) is usually applied to calculate the effect of antecedent rainfall, which can be expressed as

$$
r_{0}=k r_{1}+k^{2} r_{2}+\cdots+k^{n} r_{n}
$$




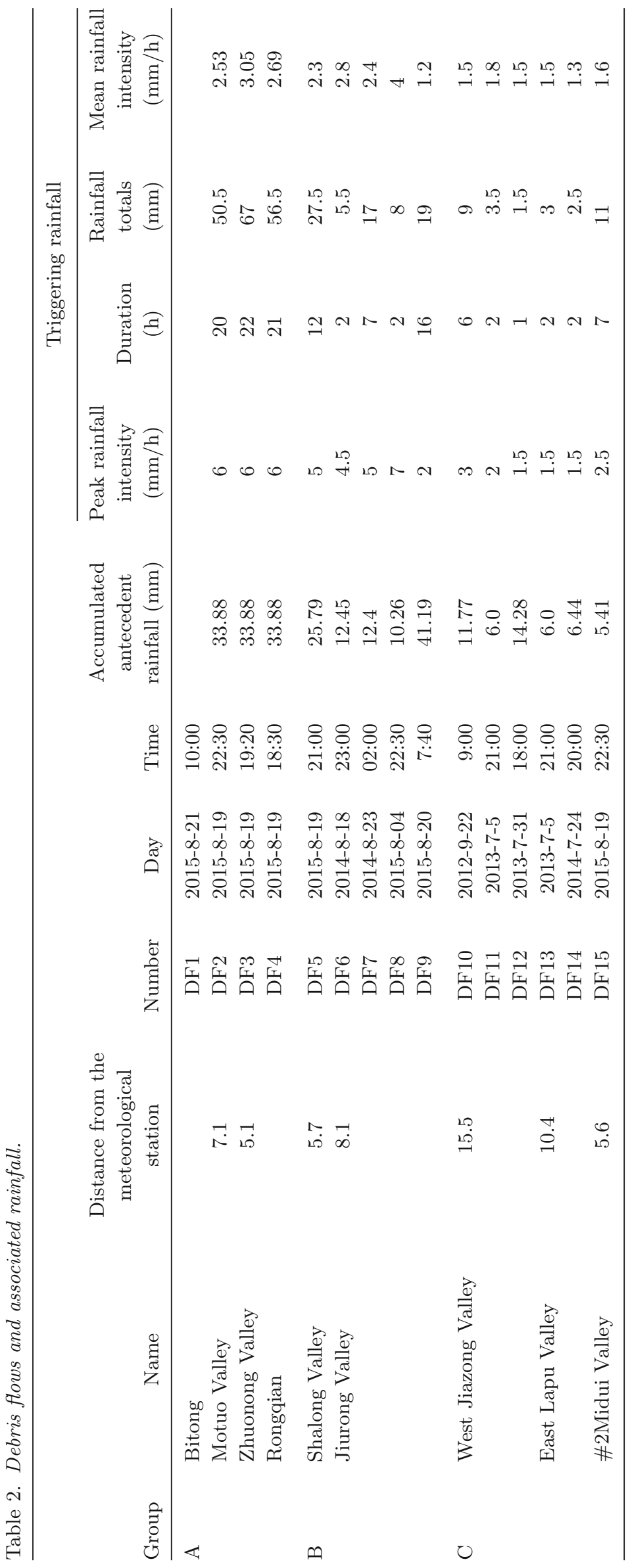




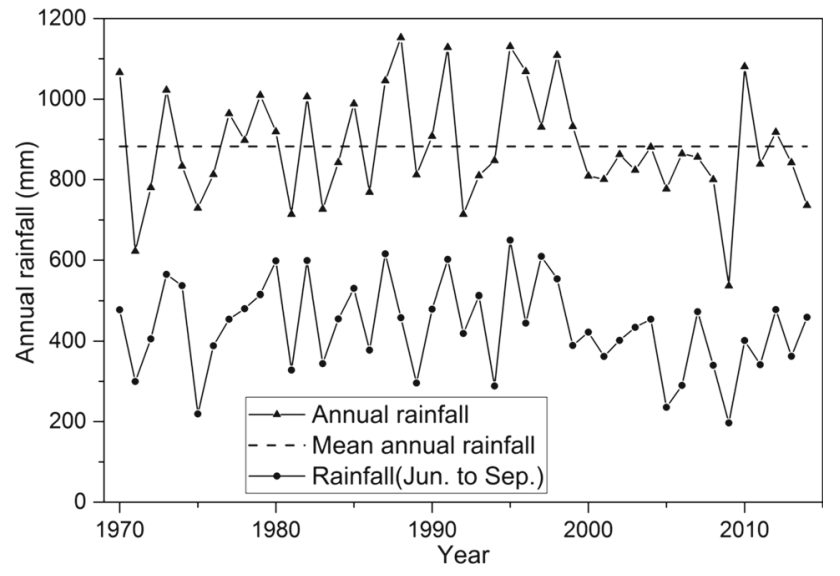

Figure 2. Fluctuation of annual rainfall at the Bomi meteorological station.

where $r_{0}$ is the antecedent daily precipitation based on the maximum regional precipitation values $(\mathrm{mm})$ for day $0, k$ is a constant for the regolith outflow, and $r_{n}$ is the maximum regional precipitation $(\mathrm{mm})$ on the $n$th day before 0 .

\section{Analysis and results}

\subsection{Rainfall characteristics}

\subsubsection{Annual rainfall}

We collected annual rainfall data from 1981 to 2014 at the Bomi meteorological station and derived a mean annual rainfall of $884 \mathrm{~mm}$. The annual rainfall peaked at $1152.6 \mathrm{~mm}$ in 1988 and dropped to $536.2 \mathrm{~mm}$ in 2009 (figure 2). Fluctuations in the annual rainfall were sharp, which might be attributed to the effect of global climate change. The annual rainfall differed each year; therefore, the data from the five newly built rain gauges over the last 4 years were used.

Most mountain stream and debris flows in the Parlung Zangbo Basin occur between June and September; thus, rainfall data during this period require greater attention. In this study, we examined the daily rainfall distribution, heavy rainfall events (including their duration and intensity), and rainfall thresholds for debris flows over the past 4 years.

\subsubsection{Distribution of daily rainfall from June to September}

Daily rainfall data are used to understand the surface discharge (Rajurkar et al. 2004; Cruse et al. 2006), debris flow thresholds (Terlien 1998; Glade et al. 2000; Chen et al. 2009), and soil erosion (Cruse et al. 2006).

Figure 3 shows the daily rainfall distribution based on daily rainfall data from the Peilong, Guxiang, Bomi, Songzong, and Midui meteorological stations from June to September in 2012-2015, except for missing data due to GPRS signal problems. According to these statistics, rainy days comprised 103, 75, 78, 77, and 55 of the days from June to September in 2012-2015, which indicates that $83 \%, 61 \%, 64 \%, 63 \%$, and $45 \%$ of the 122 days experienced rain in Peilong, Guxiang, Bomi, Songzong, and Midui, respectively. Overall, there was a similar number of rainy days in Guxiang, Bomi, and Songzong. When we compared the daily rainfall data from the five meteorological stations, the daily rainfall decreased with increasing elevation, whereas the rainfall gradient was larger in the upper and lower areas and smaller from Guxiang to Songzong. Sometimes, the rainfall gradient reversed and the daily rainfall increased in the upstream data. The peak daily rainfall days among the different meteorological stations corresponded well. In particular, rainfall days were more abundant in the downstream area.

The maximum daily rainfall (MDR) from 1961 to 2015 at the Bomi meteorological station fluctuated wildly. Most of the MDR data were near the mean value of $41 \mathrm{~mm} / \mathrm{d}$, with the lowest and highest values being 25 and $75 \mathrm{~mm} / \mathrm{d}$, respectively (figure 4). The MDR from five meteorological stations (Peilong, Guxiang, Bomi, Songzong, and Midui) is shown in figure 5 to demonstrate the distribution of the MDR in other areas of the basin. During 2012 2015, the highest MDR in Peilong, Guxiang, Bomi, Songzong, and Midui was 56.5, 50, 76, 49.5, and $34.5 \mathrm{~mm} / \mathrm{d}$, respectively; the first four rain gauges experienced the MDR on the same day (August 19, 2015), whereas $17 \mathrm{~mm}$ of rainfall occurred in Midui that day. The highest MDR of the five meteorological stations did not always occur in Peilong, where rainfall is abundant; instead, the highest MDR was in Bomi, Songzong, Peilong, and Bomi, which received $47,51,56.5$, and $76 \mathrm{~mm} / \mathrm{d}$ of rain, respectively, in 2012-2015. However, Midui always exhibited the lowest MDR.

The daily rainfall during the summer over the last 4 years had the following characteristics:

(1) Rainfall was abundant in the Parlung Zangbo Basin. In particular, rainfall was intensive in downstream areas and sometimes continued 

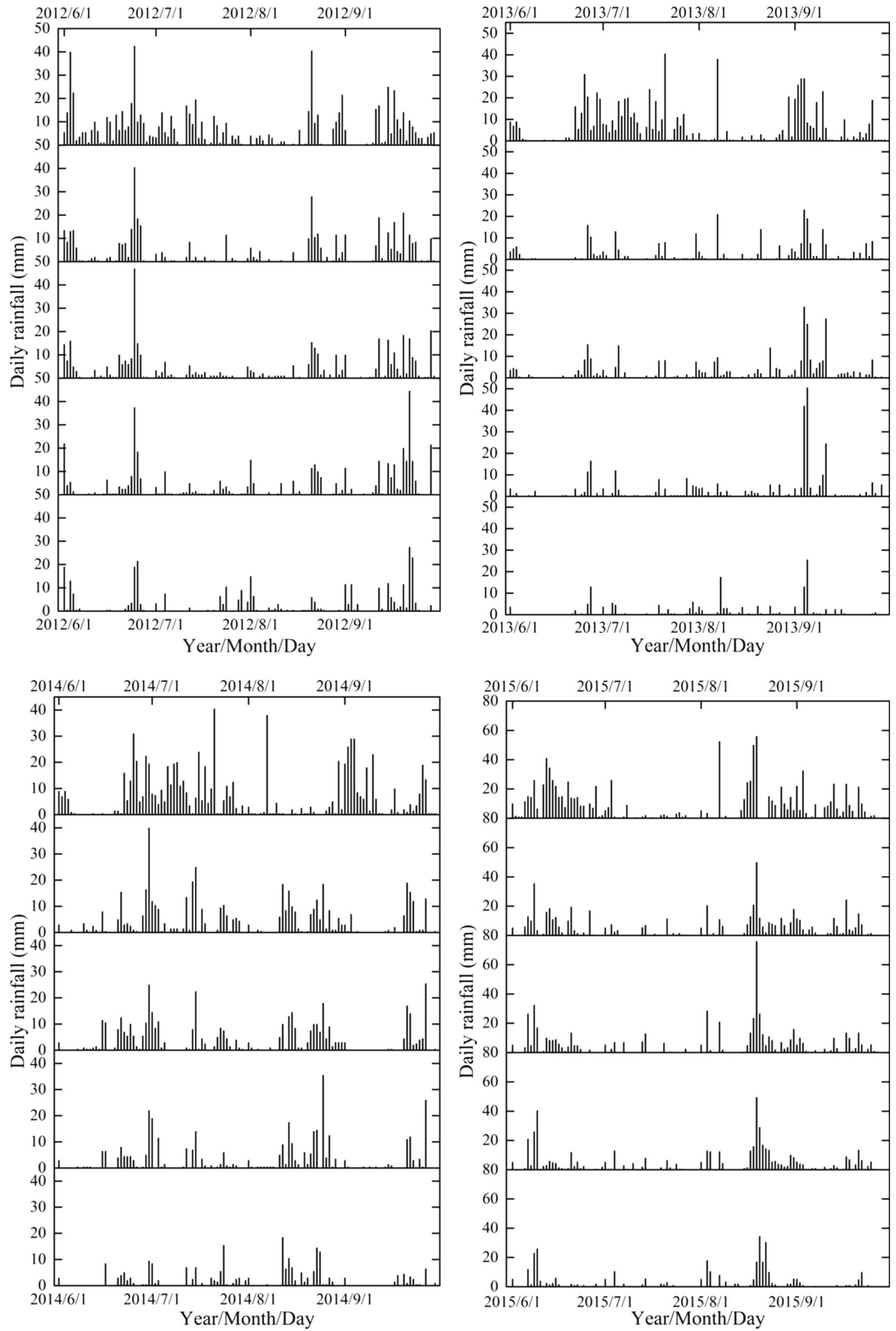

Figure 3. Daily rainfall from June to September at the Peilong, Guxiang, Bomi, Songzong, and Midui stations from top to bottom. 


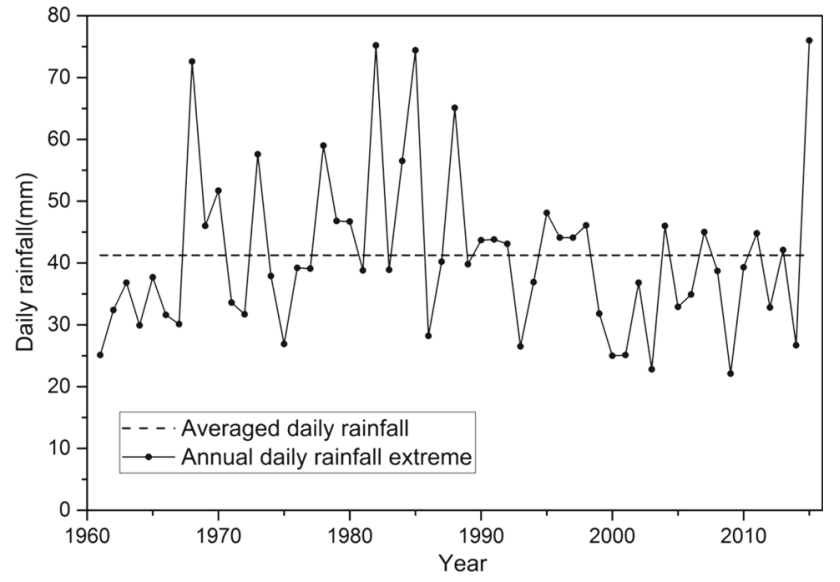

Figure 4. MDR at Bomi, 1961-2015.

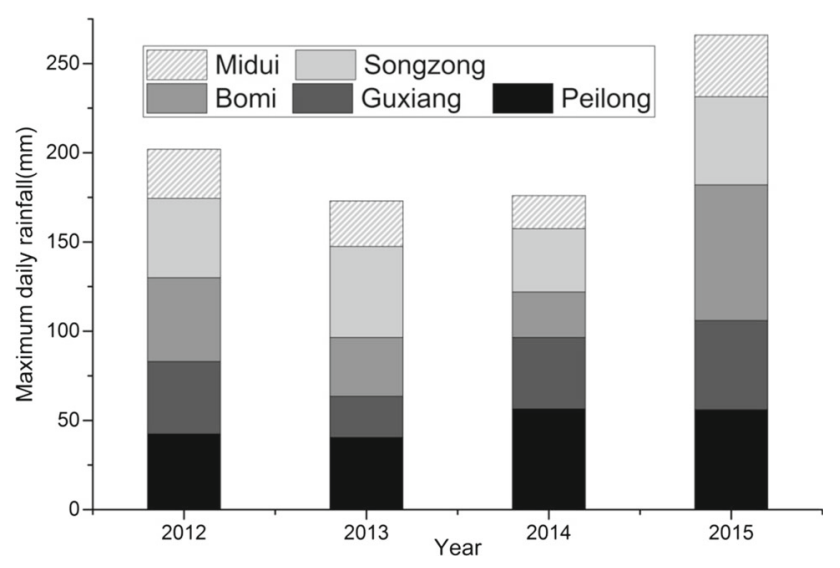

Figure 5. MDR at Parlung Zangbo, 2012-2015.

for days, whereas rainfall did not last long in upstream areas.

(2) Rainfall events exhibited time consistency. The rainfall duration in upstream areas included events when it rained downstream, and all five meteorological stations recorded the peak rainfall on the same day.

(3) Large rainfall could affect the entire basin. As wet currents from the Indian Ocean move to the north, the daily rainfall decreases towards the upstream areas. However, the rainfall gradient occasionally reversed, and higher daily rainfall was observed in Guxiang, Bomi, and Songzong compared to downstream areas, which might be attributed to obstacles along the pathway or other sources of wet currents.

(4) Several isolated convective rainfall events were observed upstream when no rainfall occurred downstream. Most of these events occurred during the afternoon, such as a short-duration thunderstorm that occurred in Bomi County when the weather was sunny in the lower and upper stream areas. This event suggests that some other current sources existed, which may be the branches of Yarlung Zangboin the southwestern area of the basin.

\subsubsection{Rainfall distribution during heavy rainfall}

A total of 134 rainfall cases over the past 4 years were chosen for our analysis. The duration of heavy rainfall varied in the Parlung Zangbo Basin. Generally, heavy rainfall in downstream areas lasted longer, whereas the duration was shorter in upstream areas (figure 6). For example, rainfall events with durations between 6 and $15 \mathrm{hr}$ comprised more than $80 \%$ of the total rainfall in Peilong, whereas only $3.23 \%$ lasted less than 5 hr. In Guxiang, Bomi, and Songzong, heavy rainfall lasted between 6 and $15 \mathrm{hr}$, whereas shortduration rainfall exhibited a higher intensity. In Midui, heavy rainfall was short-lived and lasted less than $10 \mathrm{hr}$ over the past 4 years, with nearly half of the heavy rainfall events lasting less than $5 \mathrm{hr}$.

The mean rainfall intensity was higher in the downstream and middle areas and lower in the upstream areas, whereas the gradient was quite small. In Peilong, Guxiang, Bomi, and Songzong, the mean rainfall intensity was between 2 and 3 $\mathrm{mm} / \mathrm{hr}$, with a maximum of $4-5 \mathrm{~mm} / \mathrm{hr}$ comprising $6-8 \%$ of the total, except in Guxiang. In Midui, the mean rainfall intensity was less than $3 \mathrm{~mm} / \mathrm{hr}$ (figure 6).

Variations could be observed in the peak and mean rainfall intensity throughout the basin. The maximum peak rainfall intensity declined upstream. For example, the hourly rainfall reached $12 \mathrm{~mm} / \mathrm{hr}$ in Peilong, $8 \mathrm{~mm} / \mathrm{hr}$ in Guxiang, Bomi, and Songzong, and only $4 \mathrm{~mm} / \mathrm{hr}$ in Midui (figure 7). The peak rainfall intensity was $5 \mathrm{~mm} / \mathrm{hr}$ in Peilong, constituting $32.4 \%$ of the total, whereas that in Guxiang, Bomi, and Songzong was approximately $4 \mathrm{~mm} / \mathrm{hr}$. In Midui, the peak rainfall intensity was greater than $3 \mathrm{~mm} / \mathrm{hr}$ (figure 7 ). Additionally, the peak rainfall intensity was much more likely to occur during 01:00-06:00, which constituted $75.8 \%$ of the total in Peilong and more than $40 \%$ in the remaining areas. In the middle and upper areas of the basin, high peak rainfall intensity appeared at 19:00-24:00 and 7:00-12:00, constituting 20 to $40 \%$ of the total rainfall. Furthermore, the peak rainfall intensity in the afternoon was less than $10 \%$ (figure 6). 


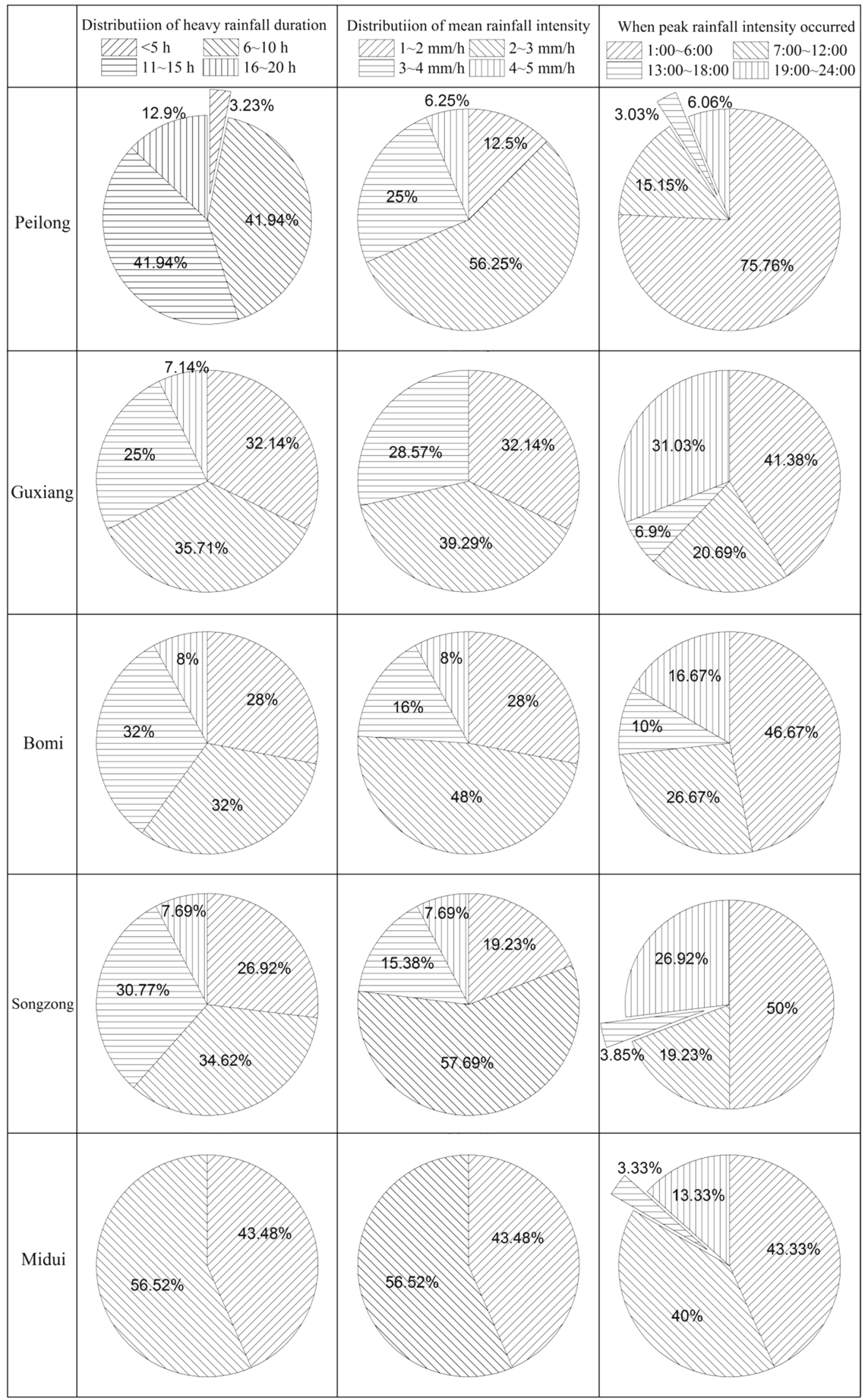

Figure 6. Hourly rainfall statistics. 


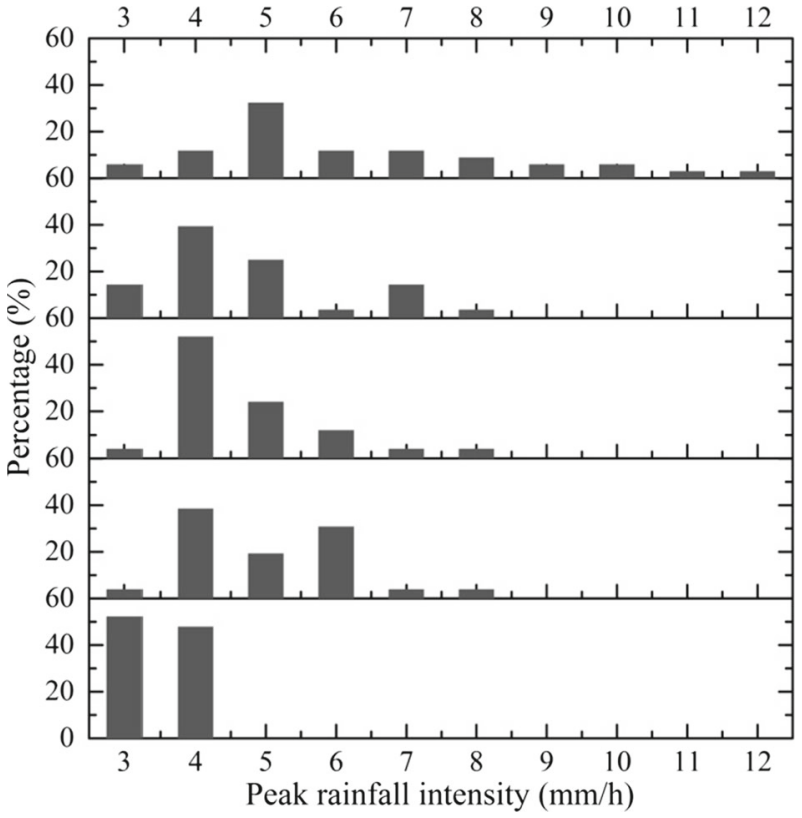

Figure 7. Distribution of the peak rainfall intensity.

\subsection{Rainfall threshold for debris flows}

The duration of rainfall events before debris flows is either long or short; thus, rainfall values are difficult to compare. In this study, the accumulated value was often used as the antecedent rainfall, and the triggering rainfall could be expressed as accumulated and triggering components. Moreover, the last 12:00 (debris flows between 0:00 and 12:00) or 24:00 (debris flows between 12:00 and 24:00) were regarded as the beginning in figure 8. Hence, debris flow cases could be shown in the later portion of the 24-hr rainfall event line (figure 8). During 12-hr rainfall events (figure 8), rainfall intensities less than $1 \mathrm{~mm} / \mathrm{hr}$ (the beginning of triggering rainfall) occurred in all 12 cases, which ensured that the entire triggering rainfall event was included in the hourly rainfall analysis.

We divided the 14 debris flows into three groups according to their locations: group A for DF1-DF3 in the middle of the Parlung Zangbo Basin, group $\mathrm{B}$ for $\mathrm{DF} 4-\mathrm{DF} 8$ in the middle-upper region, and group C for DF9-DF14 in the upper region (figure 1 , table 2).

Rainfall data were recorded for 11 debris flows (DF1-DF9, DF11, DF13 and DF14) by meteorological stations, whereas no rainfall data were recorded for the remainder (DF10 and DF12). The long-duration rainfall in the Parlung Zangbo Basin was regional; thus, we believe that the two debris flows with no rainfall records could be triggered by short, isolated, convective rainfall events. Coincidentally, these two debris flows were located upstream, which experienced no accumulated antecedent rainfall. The triggering rainfall, accumulated antecedent rainfall, peak rainfall intensity, duration, mean rainfall intensity, and total rainfall are listed in table 2 and shown in figure 8 .

\subsubsection{Antecedent rainfall}

The duration of antecedent rainfall events can be quite long, and their effects can decline with time. The duration of the antecedent rainfall depends on the depth that rainwater percolates and the water content that sediments can maintain over time. The strong frost-thaw effect in the Parlung Zangbo Basin, particularly in high-elevation source areas, would produce sediments with low clay content and high permeability (Yuan et al. 2009). Consequently, the effects of antecedent rainfall can decline quickly; thus, rainfall over the previous 3 days was included in the antecedent rainfall in this paper. The antecedent rainfall is shown by the exhaustion model in table 2 .

The accumulated rainfall ranged from several millimetres to tens of millimetres amongst the groups. In group $\mathrm{A}$, the antecedent rainfall was generally greater than $30 \mathrm{~mm}$. In group $\mathrm{B}$, this value sharply fluctuated, with 41 and $10 \mathrm{~mm}$ as the largest and smallest values, respectively. In group $\mathrm{C}$, the antecedent rainfall was $5-15 \mathrm{~mm}$. Overall, the antecedent rainfall greatly varied from relatively large in middle stream areas (group A) to small in upstream areas (group C) and was either large or small between these two groups.

\subsubsection{Triggering rainfall}

In group $\mathrm{A}$, the triggering rainfall sometimes lasted longer than $20 \mathrm{hr}$ with rainfall totals over 50 $\mathrm{mm}$. The peak rainfall intensity was approximately $6 \mathrm{~mm} / \mathrm{hr}$, and the mean rainfall intensity was approximately $3 \mathrm{~mm} / \mathrm{hr}$. In group B, the triggering rainfall ranged from 1 to $16 \mathrm{hr}$ with rainfall totals of $5.5-27.5 \mathrm{~mm}$. The peak rainfall intensity was 2-7 mm/hr, and the mean rainfall intensity was $1.2-4 \mathrm{~mm} / \mathrm{hr}$. In group $\mathrm{C}$, the triggering rainfall lasted for a short time with small rainfall totals. Both the peak and mean rainfall intensities were approximately $1.5 \mathrm{~mm} / \mathrm{hr}$. 

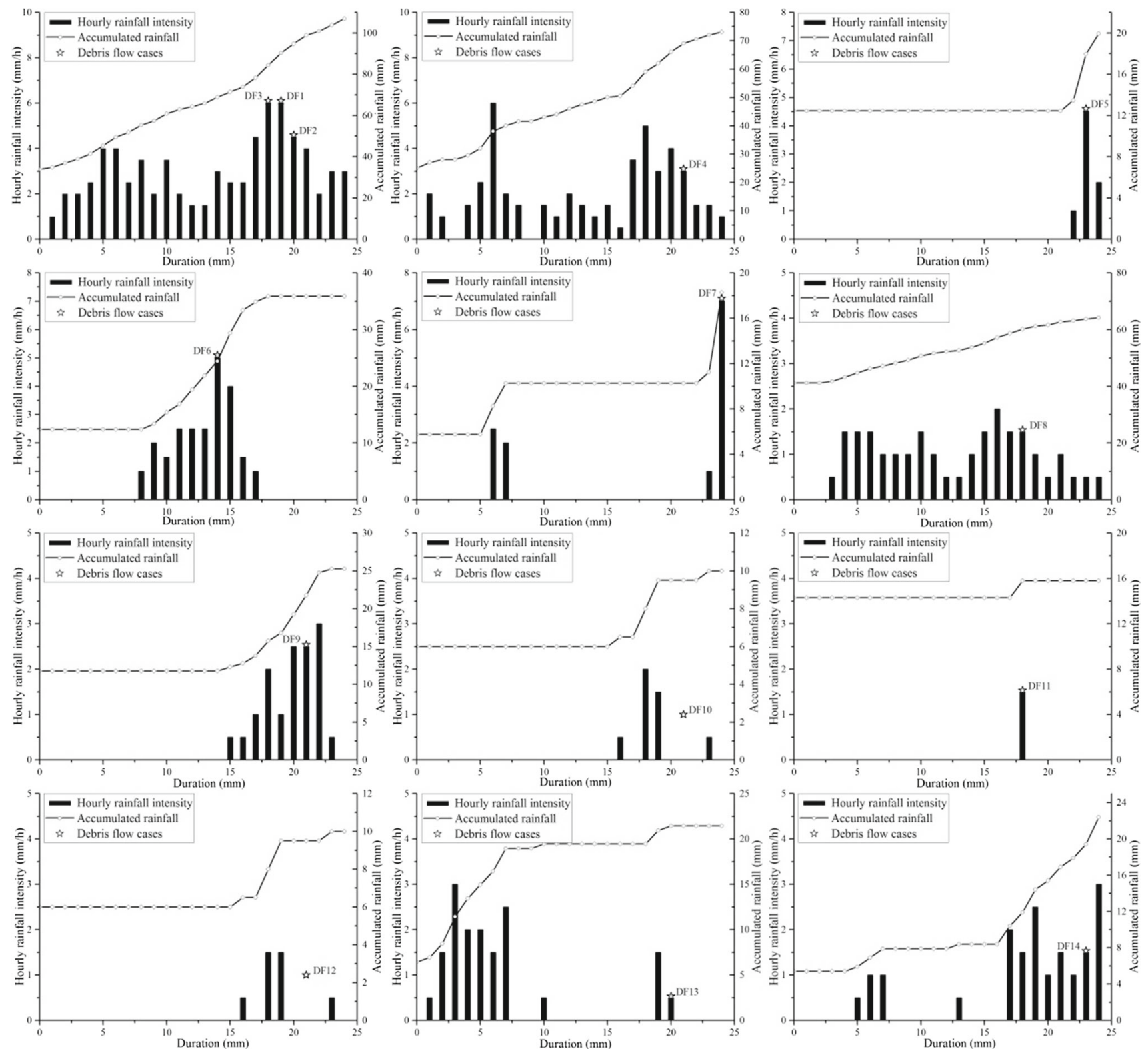

Figure 8. Rainfall process before and after debris flows.

The rainfall intensity and duration are often combined into a rainfall threshold for debris flows. The variability of the mean rainfall intensity as a function of the duration is shown in figure 9 . Figure 9 suggests that the mean rainfall intensity and the duration of the triggering rainfall were well correlated amongst the groups. In group A, the debris flows could have been generated by long-duration, high-intensity rainfall events. In group B, either long-duration, low-intensity rainfall or short-duration, high-intensity rainfall could have triggered debris flows. Finally, short-duration, high-intensity rainfall events could have triggered debris flows in group $\mathrm{C}$.

\subsection{Historical rainfall thresholds for debris flows}

We have examined debris flows over the past dozen years and compared their rainfall thresholds to those of ancient debris flows (table 3 ). Debris flows that occurred less than $50 \mathrm{~km}$ from the Bomi meteorological station were adopted because of the large rainfall gradient. The local convective rainfall events were excessive; therefore, this analysis is approximate and only serves as a reference.

The population in Parlung Zangbo is sparsely distributed; therefore, we could not determine the fixed times when a larger number of debris flows 
occurred. In this paper, data for nine debris flows were collected, and the 3-day rainfall and previous daily rainfall were regarded as the antecedent rainfall and triggering rainfall, respectively (table 3 ). Table 3 suggests that more of the triggering rainfall in the downstream of Bomi was larger than $20 \mathrm{~mm}$, whereas it was only several millimetres in upstream areas. Notably, the antecedent rainfall in the downstream area was more than $50 \mathrm{~mm}$, much larger than that in the upstream area.

\section{Discussion}

\subsection{Consistency and reversal of rainfall events}

The rainfall amount, rainfall intensity, and duration were used to analyse the rainfall characteristics, and the evolution of rainfall was more controlled by the current sources and landforms. The Indian monsoon moves towards the Tibetan

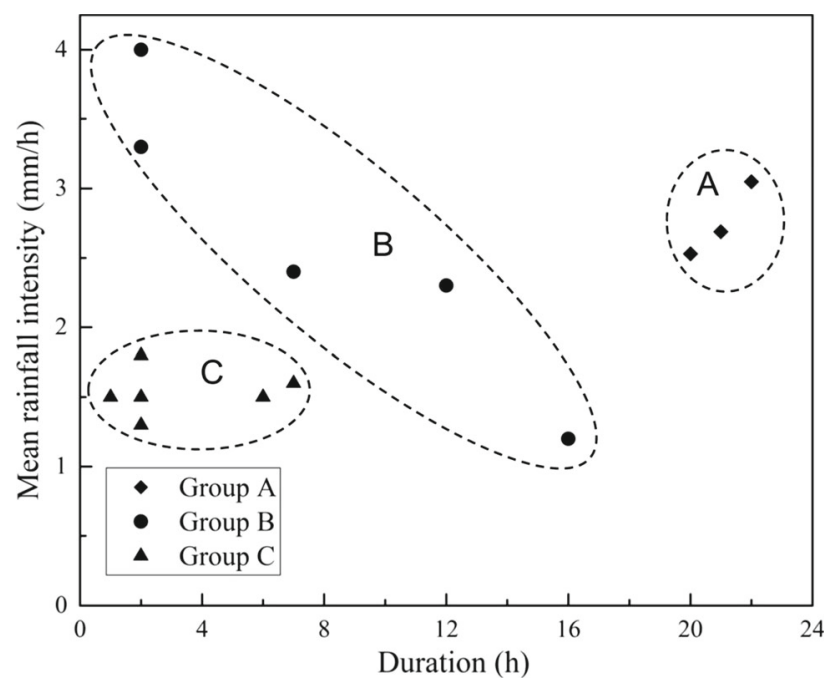

Figure 9. Mean rainfall intensity vs. duration for events that triggered debris flows.
Plateau with many warm and wet currents. As the Indian monsoon climbs up the high alpines, it cools down and produces large amounts of rainfall on the border of the Tibetan Plateau. Moreover, the Indian monsoon can penetrate into the high platform through the Yarlung Zangbo Canyon, followed by a branch such as Parlung Zangbo. The Indian monsoon declines as it climbs up along the Parlung Zangbo, producing temporally consistent rainfall events with lower rainfall amounts and duration with higher altitude, along with high gradients in the downstream and upstream areas and lower gradients in the middle of Parlung Zangbo. Additionally, the Indian monsoon can move across the southern crest through the lower bealock as a warm and wet current; after reaching the cool current in Parlung Zangbo, convective storm rainfall could occur upstream of Bomi, reversing the time and duration of rainfall events, such as strong, short, high-intensity convective rainfall.

\subsection{Rainfall threshold characteristics}

Debris flows can form when peak runoff flows over debris deposits and hydrodynamic forces act on the surface elements of the debris layer (Gregoretti 2000; Tognacca et al. 2000; Kean et al. 2013; Gregoretti et al. 2016). The concentration of runoff in the channel bottom erodes the debris surface layer and extends to the layers below, entirely or partially mobilizing the bed material and generating debris flows (Gregoretti and Fontana 2008). The infiltration of excess surface runoff is the first step for runoff-generated debris flows and can occur when the rainfall intensity is larger than the infiltration rate. The infiltration of excess surface runoff should reach a certain critical threshold, which depends more on the intensity and quantity of rainfall, the topography, and the availability

Table 3. Debris flows and associated long-term rainfall.

\begin{tabular}{|c|c|c|c|c|}
\hline No. & Name & Time & $\begin{array}{l}\text { Daily rainfall } \\
\qquad(\mathrm{mm})\end{array}$ & $\begin{array}{l}\text { 3-day rainfall before } \\
(\mathrm{mm})\end{array}$ \\
\hline 1 & Songrao & Sep. 4th, 2007 & 20.4 & 8.1 \\
\hline 2 & Wapu & Sep. 2nd, 1998 & 46.1 & 49.9 \\
\hline \multirow[t]{2}{*}{3} & \multirow[t]{2}{*}{ Baka } & Sep. 7th, 2007 & 16.2 & 63.6 \\
\hline & & Sep. 1st, 1998 & 12 & 51.8 \\
\hline \multirow[t]{3}{*}{4} & \multirow[t]{3}{*}{ West Xingkong } & Sep. 1st, 2005 & 1.2 & 0.2 \\
\hline & & Jul. 7th, 2009 & 10.3 & 11.8 \\
\hline & & Aug. 1st, 2009 & 2.3 & 7 \\
\hline 5 & East Daxing & Aug. 12nd, 2005 & 0.1 & 7.1 \\
\hline 6 & Shalong & Jul. 14th, 1990 & 0.4 & 4.91 \\
\hline
\end{tabular}


and properties of debris (Gregoretti and Fontana 2008; Kean et al. 2013; Moody et al. 2013; Sheridan et al. 2016; Dusek and Vogel 2016; Rengers et al. 2016). In other words, the rainfall threshold varies for a given steep area because the soil's hydraulic conductivity is quite different.

The hydraulic conductivity of debris is controlled by both the soil porosity and soil water repellence (Campbell and Shiozawa 1992). Soil water repellence is an ability that reduces the affinity of soils to water such that they resist wetting for a time and that declines with increasing water content (Doerr and Thomas 2000; Sheridan et al. 2016). Generally, lower infiltration is strongly associated with higher aridity (Sheridan et al. 2016; Noske et al. 2016), if the debris is not well structured; otherwise, the infiltration could remain high for well-structured debris (Nyman et al. 2011; Sheridan et al. 2016).

In the middle areas of Parlung Zangbo (Group A), long-duration rainfall is prevalent and vegetation is rich. Glacial sediment has a high porosity because of long-term freezing and thawing. During the summer, the thawing of internal ice, which is sheltered from sunlight by vegetation, can increase the porosity and water content. In the long run, sediment can form an overhead structure and the water flux can move along certain pathways, increasing the hydraulic conductivity (Sheridan et al. 2016). A larger rainfall intensity than the infiltration rate and long-term rainfall are required to generate excess surface runoff and increase the associated debris flows (Zhuang et al. 2009; Stoffel et al. 2011). Vegetation could be another reason for decreasing debris flows (Rengers et al. 2016). Sandstone and slate are widely distributed in the upstream areas (Group C). Large temperature differences between day and night can induce an intense freeze-thaw weathering effect, and large amounts of ravel deposits are present, such as talus cones. Vegetation is sparse and sunlight is strong, causing the ravels to be arid with an impermeable rock layer below. Dry ravels on steeper land have high water repellence and are not well structured, which creates low hydraulic conductivity (Moody et al. 2016; Noske et al. 2016; Sheridan et al. 2016), whereas short-duration and low-intensity rainfall can generate excess surface runoff. The dry ravels are cohesionless, and surface runoff can form rills and entrain the ravels to generate debris flows; notably, high antecedent rainfall is not required for this process (Coe et al. 2008).

The aridity, structure, and hydraulic conductivity of Group B fall between those of Groups A and
C. Long-term, low-intensity rainfall can destroy the soil aggregate, blocking pathways and decreasing the hydraulic conductivity (Mataix-Solera et al. 2011). However, short-term, high-intensity rainfall that exceeds the hydraulic conductivity can generate excess surface runoff, entrain sediment, and trigger debris flows.

In terms of physical mechanisms, the day ravels with poor structure in the upstream area have lower hydraulic conductivity than the wet glacial sediment with good structure in the middle area; therefore, a lower rainfall threshold is required to generate excess surface runoff, which can easily entrain the sediment and trigger debris flows. Similar results were obtained by Chen et al. (2014), who argued that debris flows can be triggered much more easily after long droughts according to statistics of a larger number of debris flow cases.

\subsection{Rainfall thresholds compared to other regions}

In the study area, the rainfall threshold for the 14 debris flow cases was quite small, and only the rainfall amounts for DF1-DF3 in August 2015 were comparable to the rainfall threshold for debris flows in southwestern China (Zhou and Tang 2014), the area of the Chi-Chi earthquake in Taiwan (Chen et al. 2005), and the Nepal Himalayas (Dahal and Hasegawa 2008). Indeed, the rainfall threshold in the upstream area was much smaller and was comparable to that for post-fire debris flows in California with short duration $(<10 \mathrm{~m})$ and low rainfall intensity $(1.3 \sim 4.0 \mathrm{~mm} / \mathrm{hr}$ ) (Cannon et al. 2008) and for a debris flow in Dongchuan, a drought valley in southwestern China, which had a low rainfall intensity of $1.4 \sim 26.9 \mathrm{~mm} / \mathrm{hr}$ (Guo et al. 2013).

In the upstream area of the Parlung Zangbo Basin, large amount of hillslope sediments with low hydraulic conductivity in the form of dry ravels are likely responsible for debris flows that can be easily initiated by much less rainfall or low rainfall intensity, as in burnt watersheds (Cannon et al. 2008; Kean et al. 2011). The conditions in other sections of the Parlung Zangbo Basin are more complex. Stoffel et al. (2011) found that debris flows in the Swiss Alps could be triggered by low total rainfall during early summer rainstorms, when the ablation of internal ice particles adds considerable amount of water, whereas the low ice content in moraines during the summer increases the moraines' porosity and decreases the soil strength, making this soil vulnerable to entrainment. We believe that the addition of water from the ablation of internal 
ice particles and the consequent high porosity and low strength of the sediment are responsible for triggering debris flows under low rainfall intensity. A large gap in the rainfall intensity should exist between the upstream and middle areas, but rain gauges in the downstream areas may not record the rainfall in the source area, particularly for convective rainfall in high alpine areas with large gradients. Regional rainfall records could be improved, and rain gauges in the downstream area could record triggering rainfall events.

\subsection{Combined rainfall characteristics and their effect on the rainfall threshold}

Rainfall variations can greatly affect environmental elements. The middle area of Parlung Zangbo has plenty of rainfall and rich vegetation. High trees cover a large portion of the watershed, with shrubs, grass land, and bare land occurring with higher elevation. The rainfall duration and totals are large; therefore, sediment that is sheltered by trees can be wet during the summer. Additionally, this sediment is well structured after long rainfall events. Both the rainfall duration and totals in the upstream area of Parlung Zangbo are lower. Vegetation is sparse, and trees and shrubs can be found near forks in the river, with sparse grass and bare land above. Large variations in air temperature are observed, which creates strong freeze-thaw weathering and large amounts of ravels. The rainfall duration and totals are small; combined with the intense sunshine and strong wind, the ravels are always arid and not well structured. The effect of this sediment variation created differences in the rainfall threshold.

Generally, the rainfall consistency controls the occurrence of debris flows. For example, on August 19th, 2015, a strong rainfall event triggered approximately 10 debris flows in Parlung Zangbo. This situation was more common in the middle areas and should have been triggered by long-term, high-intensity rainfall. The rainfall duration and totals were large; therefore, the sediment had a high water content, and debris flows could thus be very large (Zhuang et al. 2009; Stoffel et al. 2011). However, these rainfall patterns could be reversed, such as through strong convective rainfall in the upstream areas, which increases the rainfall totals. The rainfall threshold was small; therefore, debris flows could be triggered by convective rainfall in the upstream area, such as the debris flows in the Jiurong gully on August 4th,
2015. Here, the rainfall duration and totals were small, but sediment is abundant; therefore, the debris flows were always small but had high bulk density.

The rainfall thresholds for these debris flows varied greatly because of the large differences in the regional rainfall and soil characteristics, which can be used to divide this basin into several groups. There should be a high density of rain gauges to record local rainfall events because of the huge differences in rainfall characteristics and thresholds.

\section{Conclusions}

The Indian monsoon moves along the Parlung Zangbo and produces rainfall events. The rainfall totals, mean rainfall intensity, peak rainfall intensity, and rainfall duration in the basin consistently decline with altitude. However, this situation could become reversed, and convective storm rainfall can occur in upstream of Bomi which increases the rainfall intensity, which might be a result of obstacles or the confluence of another Indian monsoon source moving across the southern crest through the lower bealock.

The uneven distribution of rainfall changed the natural conditions of the basin and affected the rainfall threshold for debris flows. In the middle areas, the rainfall duration is long and vegetation is rich. The sediment is wet and well structured, which increases the hydraulic conductivity, and long-term, high-intensity rainfall is required to produce runoff and debris flows. Conversely, vegetation is sparse and sunlight is strong in the upstream areas, and the ravels are therefore arid with low hydraulic conductivity. In this area, shortterm rainfall can generate excess surface runoff and debris flows without high antecedent rainfall. Between these two areas, the hydraulic conductivity is neither too large nor too small, and both long-term, low-intensity rainfall and shortterm, high-intensity rainfall can trigger debris flows.

Large differences exist in the regional rainfall and rainfall thresholds of debris flows, and this basin should be divided according to the rainfall thresholds from the monitoring and warning of debris flows. Rain gauges should be set differently, and indeed, more rain gauges should be placed in the upstream areas, where local convective rainfall can trigger debris flows. 


\section{Acknowledgements}

This research was supported by the National Natural Science Foundation of China (Grant No. 41402283), the STS project of CAS (Grant No. KFJ-EW-STS-094), and the project of the Key Lab. of Mountain Hazards and Earth Surface Processes, CAS. We wish to acknowledge Associate Editor and the anonymous reviewers for their constructive comments, which helped us in improving the content and presentation of the manuscript.

\section{References}

Arenson L U and Springman S M 2005 Mathematical descriptions for the behaviour of ice-rich frozen soils at temperatures close to $0^{\circ} \mathrm{C}$; Canadian Geotech. J. 42(2) 431-442.

Calvo-Alvarado J C, Jiménez-Rodríguez C D and JiménezSalazar V 2014 Determining rainfall erosivity in Costa Rica: A practical approach; Mountain Res. Develop. 34(1) 48-55.

Campbell G S and Shiozawa S 1992 Predicting of hydraulic properties of soils using particle-size distribution and bulk density data; In: Proceeding of the International Workshop on Indirect Methods for Estimating the Hydraulic Properties of Unsaturated Soils (eds) van Genuchten MTh, Leij F J and Lund L J, US Department of Agriculture (Riverside, CA, 11-13 October 1989), pp. 317-328.

Cannon S H, Gartner J E, Wilson R C, Bowers J C and Laber J L 2008 Storm rainfall conditions for floods and debris flows from recently burned areas in southwestern Colorado and southern California; Geomorphology 96(3) 250-269.

Chen C Y, Chen T C, Yu F C, Yu W H and Tseng C C 2005 Rainfall duration and debris-flow initiated studies for real-time monitoring; Environ. Geol. 47(5) 715-724.

Chen N S, Lu Y, Zhou H B, Deng M F and Han D W 2014 Combined impacts of antecedent earthquakes and droughts on disastrous debris flows; J. Mountain Sci. 11(6) 1507-1520.

Chen N S, Yang C L, Zhou W, Hu G S, Li H and Han D 2009 The critical rainfall characteristics for torrents and debris flows in the Wenchuan earthquake stricken area; J. Mountain Sci. 6(4) 362-372.

Coe J A, Kinner D A and Godt J W 2008 Initiation conditions for debris flows generated by runoff at Chalk Cliffs, central Colorado; Geomorphology 96(3) 270-297.

Cruse R, Flanagan D and Frankenberger J et al. 2006 Daily estimates of rainfall, water runoff, and soil erosion in Iowa; J. Soil Water Conser. 61(4) 191-199.

Dahal R and Hasegawa S 2008 Representative rainfall thresholds for landslides in the Nepal Himalaya; Geomorphology 100(3) 429-443.

Decaulne A, Saemundsson T H and Petursson O 2005 Debris flows triggered by rapid snowmelt in the Gleidarhjalli area, northwestern Iceland; Geografiska Annaler 87(4) $487-500$
Doerr S H and Thomas A D 2000 The role of soil moisture in controlling water repellency: New evidence from forest soils in Portugal; J. Hydrol. 23 134-147.

Dusek J and Vogel T 2016 Hillslope-storage and rainfallamount thresholds as controls of preferential stormflow; J. Hydrol. 534 590-605.

Giannecchini R, Galanti Y and Amato Avanzi G D 2012 Critical rainfall thresholds for triggering shallow landslides in the Serchio River Valley (Tuscany, Italy); Nat. Hazards Earth Syst. Sci. 12(3) 829-842.

Glade T, Crozier M and Smith P 2000 Applying probability determination to refine landslide-triggering rainfall thresholds using an empirical 'Antecedent Daily Rainfall Model'; Pure Appl. Geophys. 157(6-8) 1059-1079.

Godt J W, Baum R L and Chleborad F A 2006 Rainfall characteristics for shallow landsliding in Seattle, Washington, USA; Earth Surf. Process. Landf. 31(1) 97-110.

Gregoretti C 2000 The initiation of debris flow at high slopes: Experimental results; J. Hydraul. Res. 38 83-88.

Gregoretti C and Fontana G D 2008 The triggering of debris flow due to channel-bed failure in some alpine headwater basins of the Dolomites: Aanalyses of critical runoff; Hydrol. Process. 22 2248-2263.

Gregoretti C, Degetto M, Bernard M, Crucil G, Pimazzoni A, De VG, Berti M, Simoni A and Lanzoni S 2016 Runoff of small rocky headwater catchments: Field observations and hydrological modeling; Water Resour. Res. 52 81388158, https://doi.org/10.1002/2016WR018675.

Guo X J, Cui P and Li Y 2013 Debris flow warning threshold based on antecedent rainfall: A case study in Jiangjia Ravine, Yunnan, China; J. Mountain Sci. 10(2) 305-314.

Guzzetti F, Peruccacci S, Rossi M and Stark C P 2008 The rainfall intensity-duration control of shallow landslides and debris flows: An update; Landslides 5(1) $3-17$.

Iverson R M, Reid M E and LaHusen R G 1997 Debris flows mobilization from landslides; Ann. Rev. Earth Planet. Sci. 25(1) $85-138$.

Jan C D and Lee M H 2004 A debris flow rainfall-based warning model; J. Chinese Soil Water Conserve 35 275285 (in Chinese).

Kean J W, McCoy S W, Tucker G E, Staley D M and Coe J A 2013 Runoff-generated debris flows: Observations and modeling of surge initiation, magnitude, and frequency; J. Geophys. Res. Earth Surf. 118 2190-2207.

Kean J W, Staley D M and Cannon S H 2011 In situ measurements of post-fire debris flows in southern California: Comparisons of the timing and magnitude of 24 debrisflow events with rainfall and soil moisture conditions; J. Geophys. Res. Earth Surf. 116(F04019), https://doi. org/10.1029/2011jf002005.

Lin G W and Chen H 2012 The relationship of rainfall energy with landslides and sediment delivery; Eng. Geol. $\mathbf{1 2 5}$ 108-118.

Liu J K, Cheng Z L and Li Q 2013 Meteorological conditions for frequent debris flows from Guxiang glacier, Mount Nyenchen Tanglha, China; Mountain Res. Dev. 33(1) 95102.

Liu Y 2013 Research on the typical debris flows chain based on RS in Palongzangbu Basin of Tibet, Chengdu University of Science and Technology, Master thesis (in Chinese). 
Lu J Y, Su C C, Lu T F and Maa M M 2008 Number and volume raindrop size distributions in Taiwan; Hydrol. Process. 22 2148-2158.

Lu R R, Tang B X and Zhu P Y 1999 Debris flow and environment in Tibet, Press of Chengdu Science and Technology, Chengdu, China (in Chinese).

Lu R and Li D J 1989 Ice-snow-melt debris flows in the Dongru Longba Bomi county, Xizang; J. Glaciol. Geocryol. 11 148-160 (in Chinese).

Luo Y, He S M and He J C 2014 Effect of rainfall patterns on stability of shallow landslide; Earth Sci. J. China Univ. Geosci. 39(9) 1357-1363 (in Chinese).

Mataix-Solera J, Cerda A, Arcenegui V, Jordan A and Zavala L M 2011 Fire effects on soil aggregation: A review; Earth-Sci. Rev. 109 44-60.

Moody J A, Ebel B A, Nyman P, Martin D A, Stoof C and McKinley R 2016 Relations between soil hydraulic properties and burn severity; Int. J. Wildland Fire 25(3) 279-293.

Moody J A, Shakesby R A, Robichaud P R, Cannon S H and Martin D A 2013 Current research issues related to post-wildfire runoff and erosion processes, Earth Sci. Rev. 122 10-37.

Noske P J, Nyman P, Lane P N and Sheridan G J 2016 Effects of aridity in controlling the magnitude of runoff and erosion after wildfire; Water Resour. Res. 52 1-19.

Nyman P, Sheridan G J, Smith H G and Lane P N J 2011 Evidence of debris flow occurrence after wildfire in upland catchments of south-east Australia; Geomorphology 125(3) 383-401.

Rahardjo H, Ong T H, Rezaur R B and Leong E C 2007 Factors controlling instability of homogeneous soil slopes under rainfall; J. Geotech. Geoenviron. Eng. 133(12) 1532-1543.

Rahimi A, Rahardjo H and Leong E C 2010 Effect of antecedent rainfall patterns on rainfall-induced slope failure; J. Geotech. Geoenviron. Eng. 137(5) 483-491.

Rajurkar M P, Kothyari U C and Chaube U C 2004 Modeling of the daily rainfall-runoff relationship with artificial neural network; J. Hydrol. 285(1) 96-113.

Rengers F K, McGuire L A, Coe J A, Kean J W, Baum R L, Staley D M and Godt J W 2016 The influence of vegetation on debris-flow initiation during extreme rainfall in the northern Colorado Front Range; Geology 44(10) $823-826$.

Sassa K and Wang G H 2005 Mechanism of landslidetriggered debris flows: Liquefaction phenomena due to the undrained loading of torrent deposits, In: Debris-flow Hazards and Related Phenomena (eds) Jakob M and Hungr O, Springer, Germany, pp. 81-104.

Schneuwly-Bollschweiler M and Stoffel M 2012 Hydrometeorological triggers of periglacial debris flows in the Zermatt valley (Switzerland) since 1864; J. Geophys. Res.: Earth Surf. 117 F02033.

Sheridan G J, Nyman P, Langhans C, Cawson J, Noske P J, Oono A, Rene Van der Sant and Lane P N 2016 Is aridity a high-order control on the hydro-geomorphic response of burned landscapes?; Int. J. Wildland Fire 25(3) 262-267.

Stoffel M, Bollschweiler M and Beniston M 2011 Rainfall characteristics for periglacial debris flows in the Swiss Alps: Past incidences - potential future evolutions; $\mathrm{Cli}$ matic Change 105(1-2) 263-280.

Terlien M T J 1998 The determination of statistical and deterministic hydrological landslide triggering thresholds; Environ. Geol. 35(2-3) 124-130.

TFITP (Team of field investigation on Tibetan Plateau of Chinese Academic of Sciences) 1982 Physical Geography of Tibet; Beijing, Science Press, pp. 47-51.

Tognacca C, Bezzola G R and Minor H E 2000 Threshold criterion for debris-flow initiation due to channel bed failure; In: Proceedings Second International Conference on Debris Flow Hazards Mitigation, Prediction and Assessment (ed.) Wieczoreck G F, Taipei, pp. 89-97.

Tsai T L and Wang J K 2011 Examination of influences of rainfall patterns on shallow landslides due to dissipation of matric suction; Environ. Earth Sci. 63(1) 65-75.

Van D A, Bruijnzeel L A and Rosewell C J 2002 Rainfall intensity-kinetic energy relationship: A critical literature appraisal; J. Hydrol. 261 1-23.

Yuan G X, Shang Y J and Lin D M 2009 Engineering geological properties and stability analysis of moraine debris slopes in Palong River drainage area along Sichuan-Tibet highway; J. Eng. Geol. 17(2) 188-194 (in Chinese).

Zhou W and Tang C 2014 Rainfall thresholds for debris flow initiation in the Wenchuan earthquake-stricken area, southwestern China; Landslides 11(5) 877-887.

Zhou W, Tang C, Van A T W and Zhou C 2014 Rainfalltriggering response patterns of post-seismic debris flows in the Wenchuan earthquake area; Nat. Hazards $\mathbf{7 0 ( 2 )}$ 1417-1435.

Zhuang J Q, Cui P, Ge Y G and Hong Y 2009 Relationship between rainfall characteristics and total amount of debris flow; J. Beijing Forestry University 31(4) 77-83 (in Chinese). 